\title{
A proibição do non liquet e o princípio da inafastabilidade do controle jurisdicional*
}

\section{The non liquet prohibition and the non-obviation of judiciary jurisdiction principle}

\author{
Rafael Lorenzo-Fernandez Koatz**
}

\section{RESUMO}

Sustenta-se, com fundamento no art. 5ํㅡ, XXXV, da Constituição (inafastabilidade do controle jurisdicional), que o juiz não pode deixar de julgar uma causa que lhe foi submetida (proibição de juízos de non liquet). $\mathrm{O}$ propósito deste artigo é discutir essa proposição a partir da teoria dos direitos fundamentais. Pretende-se demonstrar: (i) que a inafastabilidade do controle jurisdicional tem característica de princípio, o que impõe sua aplicação de acordo com as possibilidades fáticas e jurídicas subjacentes; (ii) que a Constituição não veda de forma absoluta o non liquet e que ele pode ser válido, em circunstâncias excepcionais, para ampliar o diálogo institucional; e (iii) que o enquadramento do art. 5으, XXXV, como princípio traz importantes consequências práticas.

Artigo recebido em 14 de maio de 2014 e aprovado em 24 de outubro de 2014. DOI: http:// dx.doi.org/10.12660/rda.v270.2015.58741

** Universidade do Estado do Rio de Janeiro. Rio de Janeiro, Rio de Janeiro, Brasil. E-mail: rafael. koatz@gmail.com.

Doutor e mestre em direito público pela Uerj. Advogado no Rio de Janeiro. 


\section{PALAVRAS-CHAVE}

Non liquet - inafastabilidade do controle judicial - teoria dos direitos fundamentais - princípios - regras

\section{ABSTRACT}

Based on the provisions of Article 5, XXXV, of Brazilian Constitution (nonobviation of judiciary jurisdiction), some believe a judge cannot refrain from judging a claim presented to judiciary (prohibition of non liquet). The purpose of this article is to discuss such proposition, based on the Theory of Fundamental Rights. Its purpose is to demonstrate (i) that such constitutional provision contain characteristic of principles, imposing that such provisions be applied in accordance with the legal and factual possibilities; (ii) that the Constitution does not entirely forbid judges to declare non liquet, accepted in exceptional circumstances to enhance the institutional dialogue and (iii) such understanding of Article 5, XXXV as a principle has several important consequences.

\section{KEYWORDS}

Non liquet - principle of non-obviation of jurisdiction - theory of fundamental rights - principles - rules

\section{Introdução}

Tanto a Lei de Introdução às Normas do Direito Brasileiro ${ }^{1}$ quanto o Código de Processo Civil brasileiro vedam o que se convencionou chamar de non liquet. ${ }^{2}$ Com efeito, o art. 4ำ da Lei de Introdução estabelece que, "quando

1 Decreto-Lei no 4.657/1942. Trata-se da nova denominação da vetusta Lei de Introdução ao Código Civil Brasileiro. A Lei n⿳o 12.376/2010 alterou a ementa do referido decreto-lei, ampliando seu campo de aplicação a todas as normas do direito brasileiro.

2 A expressão latina non liquet, como ensina George Marmelstein, "é uma abreviatura da frase 'iuravi mihi non liquere, atque ita iudicatu illo solutus sum', que significa mais ou menos isso: 'jurei que o caso não estava claro o suficiente e, em consequência, fiquei livre daquele julgamento'. Ao declarar o 'non liquet', o juiz romano se eximia da obrigação de julgar os casos nos quais a resposta jurídica não era tão nítida". Cf. MARMELSTEIN, George. O asno de Buridano, o non liquet e as katchangas. Disponível em: <http://direitosfundamentais.net/2009/01/07/o-asnode-buridano-o-non-liquet-e-as-katchangas/>. Acesso em: 10 mar. 2012. "Non Liquet. Lat. is not clear. In the Roman courts, when any of the judges after the hearing of a cause, were not satisfied that the case was made clear enough for them to pronounce a verdict, they were privileged to signify this opinion 
a lei for omissa, o juiz decidirá o caso de acordo com a analogia, os costumes e os princípios gerais de direito".

$\mathrm{O}$ art. 126 do Código de Processo Civil brasileiro, por sua vez, prescreve que "o juiz não se exime de sentenciar ou despachar alegando lacuna ou obscuridade da lei. No julgamento da lide caber-lhe-á aplicar as normas legais; não as havendo, recorrerá à analogia, aos costumes e aos princípios gerais de direito". ${ }^{3}$ Tais dispositivos ${ }^{4}$ impedem que o magistrado se esquive de julgar uma causa sob a alegação de que não há comando legal a reger a situação concreta que lhe foi submetida ou porque tem dúvidas a respeito de quem deve sair vitorioso da demanda.

A proibição do non liquet é um axioma ${ }^{5}$ raramente contestado ou debatido no direito brasileiro. O Superior Tribunal de Justiça (STJ) e o Supremo Tribunal Federal (STF) já se posicionaram, ambos, no sentido da proibição

by casting a ballot inscribed with the letters 'N. L.' the abbreviated form of the phrase non liquet." (BLACK, Henry Campbell. Black's law dictionary. 4. ed. St. Paul: West Publishing Co., 1951). Tradução livre: Non Liquet, do latim, não é claro. Nas cortes romanas, quando qualquer juiz, após ouvir uma causa, não ficava satisfeito, pois considerava que o caso não havia sido exposto de forma suficientemente clara a ponto de ensejar a pronúncia de um veredito, eles tinham a possibilidade de apontar esse fato colocando as letras "N. L", forma abreviada de non liquet.

3 O anteprojeto do novo Código de Processo Civil, elaborado em 2010, estabelece, em seu art. 108, regra análoga a do art. 126 do atual CPC. Confira-se: "Art. 108. O juiz não se exime de decidir alegando lacuna ou obscuridade da lei, cabendo-lhe, no julgamento da lide, aplicar os princípios constitucionais e as normas legais; não as havendo, recorrerá à analogia, aos costumes e aos princípios gerais de direito". Disponível em: <www.senado.gov.br/senado/ novocpc/pdf/Anteprojeto.pdf>. Acesso em: 10 mar. 2012.

4 Frederico Widson da Silva Dantas enumera, ainda, outros dispositivos infraconstitucionais que corroborariam a proibição de non liquet: arts. 127 e 1.109 do CPC; art. 8o da CLT (DecretoLei no 5.452/42); art. 108 do CTN (Lei no 5.172/1966) e art. 7o do CDC (Lei nº 8.078/90). Cf. DANTAS, Frederico Widson da Silva. O princípio constitucional da inafastabilidade: estudo com enfoque no ativismo judicial. Revista Emasfe - Escola de Magistratura Federal da 5를. Região, n. 17, p. 83-114, 2008.

5 De acordo com o Dicionário Michaelis, axioma significa: "1 Princípio evidente, que não precisa ser demonstrado. 2 Máxima, sentença. 3 Norma admitida como princípio". Disponível em: $<$ http://michaelis.uol.com.br/>. Acesso em: 10 mar. 2012. No mesmo sentido, a Wikipedia registra que "axioma é uma sentença ou proposição que não é provada ou demonstrada e é considerada como óbvia ou como um consenso inicial necessário para a construção ou aceitação de uma teoria. Por essa razão, é aceito como verdade e serve como ponto inicial para dedução e inferências de outras verdades (dependentes de teoria)". Disponível em: <http://pt.wikipedia.org/wiki/Axioma>. Acesso em: 10 mar. 2012. Cf.: "AXIOMA. Um dos significados da palavra 'axioma' é dignidade. Por derivação, 'axioma' significa 'o que é digno de ser estimado, acredito ou valorado'. Nos Ant. Post. (I,2,72 a 1955), de Aristóteles, o tema axioma ainda tem este significado: os axiomas são, para o Estagirita, princípios evidentes que constituem o fundamento de toda ciência. Em tal caso, os axiomas são proposições irredutíveis, princípios gerais aos quais toda as demais proposições se reduzem e nos quais estas últimas necessariamente se apoiam. Desde este ponto de vista, ao destacar a evidência própria do axioma, tende-se para uma espécie de intuicionismo psicológico. Para essas mudanças contribuíram sobretudo a matemática e a metalógica contemporâneas. Estas distinguem entre axiomas e teoremas. Os primeiros são enunciados primitivos 
do non liquet, sem realizarem maiores indagações a respeito do acerto ou do equívoco dessa conclusão. Da jurisprudência do STF colhe-se trecho do voto do ministro Carlos Ayres Britto no qual se consignou que:

se ao Legislativo não se pode impor a obrigação de legislar, ao Judiciário se impõe, sim, a obrigação de julgar. É proibido, no âmbito do Judiciário, a formulação daquele juízo de non liquet, de não resolver a causa. $\mathrm{O}$ juiz de qualquer instância, o Tribunal de qualquer natureza tem que solver a questão, liquidar a questão para corresponder a esse prestígio máximo que a Constituição lhes deu ao dizer que a lei não excluirá da apreciação do Poder Judiciário lesão ou ameaça a direito. ${ }^{6}$

A doutrina e a jurisprudência costumam apontar como fundamento constitucional para a vedação do non liquet o art. 5으, inciso XXXV, da Constituição da República, o qual estabelece que "a lei não excluirá da apreciação do Poder Judiciário lesão ou ameaça a direito". Alega-se que a proibição é importante para resguardar o sistema jurídico do colapso. Com efeito, aduz-se que, para que seja possível viver em sociedade, é preciso que o Estado disponha de instrumentos jurídicos para pacificação social. Sustenta-se, ainda, que, a partir do momento que o Estado proibiu o exercício da autotutela, assumiu o dever de prestar a jurisdição em toda e qualquer hipótese. ${ }^{7}$ Nesse sentido, se o juiz pudesse deixar de decidir, os conflitos sociais não seriam solucionados e a própria configuração do Estado restaria comprometida. ${ }^{8}$

(às vezes também chamados postulados) que se aceitam como verdadeiros sem provas de sua validade; os segundos são enunciados cuja validade se submete à prova. Axiomas e teoremas são, portanto, elementos integrantes de todo sistema dedutivo". MORO, José Ferrater. Dicionário de filosofia. Tradução de Roberto Leal. São Paulo: Martins Fontes, 1993.

6 Cf. STF, HC no 91.352, rel. min. Menezes Direito, Tribunal Pleno, j. em 28.2.2008, DJe-070; grifou-se. No mesmo sentido, veja-se: HC 91.041, rel. min. Cármen Lúcia, rel. p/ acórdão min. Carlos Britto, Primeira Turma, j. em 5.6.2007, DJe-082; RE no 377040, rel. min. Moreira Alves, j. 28.3.2003, DJ 12.5.2003; HC 93443, rel. min. Cármen Lúcia, Primeira Turma, j. 29.4.2008, DJe117. No STJ, veja-se, entre outros, o REsp 840.690/DF, rel. min. Mauro Campbell Marques, Segunda Turma, j. em 19/8/2010, DJe 28/9/2010.

7 "A primeira garantia que o texto revela é a de que cabe ao Poder Judiciário o monopólio da jurisdição, (...). A segunda garantia consiste no direito de invocar a atividade jurisdicional sempre que se tenha como lesado ou simplesmente ameaçado um direito, individual ou não, pois a Constituição já não mais o qualifica de individual, no que andou bem, porquanto a interpretação sempre fora a de que o texto anterior já amparava direitos, p. ex., de pessoas jurídicas ou de outras instituições ou entidades não individuais, e agora hão de levar-se em conta os direitos coletivos também." SILVA, José Afonso da. Curso de direito constitucional positivo. 27. ed. São Paulo: Malheiros, 2006. p. 431.

8 "A utilidade prática da proibição 'non liquet' é inegável. Se o juiz se eximisse de proferir uma decisão toda vez que estivesse em dúvida, haveria grande probabilidade de o sistema entrar em colapso, pois são muitas as situações em que isso ocorre." George Marmelstein, O asno de 
Não questionamos esses argumentos. Em nossa compreensão, a proibição de non liquet exerce, efetivamente, um importante papel. Isso é especialmente verdadeiro nas sociedades contemporâneas, marcadas por desacordos morais e pela constante submissão de casos difíceis ao Poder Judiciário. De fato, se o juiz pudesse se eximir de julgar os casos difíceis ${ }^{9}$ ou as questões em que estivesse em dúvida, não seria possível viver em comunidade. ${ }^{10}$ Não obstante isso, em nosso entendimento, não há uma vedação total à prática do non liquet. Ao contrário. Entendemos que, em algumas situações, essa decisão pode se mostrar legítima.

O propósito deste trabalho é o de demonstrar (i) que a inafastabilidade do controle jurisdicional ostenta a característica de princípio jurídico, aplicável de acordo com as condições fáticas e jurídicas subjacentes, ${ }^{11} \mathrm{e}$ (ii) que a conclusão de que o art. $5^{\circ}, \mathrm{XXXV}$, da CRFB vedaria, de forma absoluta, a prática de juízos de non liquet não se sustenta à luz da teoria dos direitos fundamentais. A tese que se defende, neste estudo, é a de que a intensidade da incidência do princípio da inafastabilidade do controle jurisdicional depende do grau de jurisdição e varia verticalmente: o núcleo essencial do princípio, que ostenta a característica de regra e é, por essa razão, imponderável, situase no primeiro grau de jurisdição, ao passo que seu halo mais externo, o qual é, por sua natureza, ponderável, envolve a competência recursal e situa-se no âmbito dos Tribunais Superiores.

Para demonstrar essa tese, este estudo foi subdividido em sete tópicos. O objetivo do segundo item é o de demonstrar que, à luz da teoria dos direitos fundamentais, a inafastabilidade do controle jurisdicional tem natureza

Buridano, o non liquet e as katchangas, op. cit.

9 É importante notar que toda discussão em torno dos casos difíceis - e da necessidade de definição de critérios para sua solução - pressupõe a ideia de indeclinabilidade do controle jurisdicional. De fato, se o juiz pudesse deixar de apreciar tais casos, não faria sentido discutir discricionariedade judicial (Herbert Hart) e completude do ordenamento jurídico (Ronald Dworkin). HART, H. L. A. O conceito de direito. Tradução de Antônio de Oliveira Sette Câmara. São Paulo: WMF Martins Fontes, 2009; e, por todas as obras, DWORKIN, Ronald. Levando os direitos à sério. 3. ed, São Paulo: WMF Martins Fontes, 2010.

10 Interessante crítica é desenvolvida por George Marmelstein. Para o referido juiz federal, "uma das principais causas da tradicional arrogância e empáfia de muitos juízes decorre, em alguma medida, dessa obrigação a eles imposta de terem que decidir tudo, de não poderem demonstrar ou confessar ignorância. A proibição 'non liquet' não abre espaço para que os juízes exercitem a humildade intelectual. Em consequência, muitas vezes, o juiz, inconscientemente, transforma essa obrigação de julgar tudo em uma falsa crença de que sabe tudo e que é, portanto, capaz de ser o senhor onipresente e onisciente da verdade e da justiça". George Marmelstein, $O$ asno de Buridano, o non liquet e as katchangas, op. cit.

11 O princípio da inafastabilidade do controle jurisdicional é também conhecido como princípio da tutela jurisdicional efetiva ou de acesso à justiça. 
de princípio, e não de regra. O terceiro tópico discorre sobre o âmbito de proteção do princípio da inafastabilidade para evidenciar que, embora ele seja normativo, dependente, portanto, de conformação legislativa, o legislador ordinário não pode desvirtuá-lo, violando o seu núcleo essencial. O tópico que se segue discorre sobre o núcleo essencial como limite dos limites à conformação e à restrição legislativa de direitos fundamentais e apresenta, de forma sintética, as teorias que buscam explicá-lo. Na sequência, pretendese identificar o núcleo essencial e o halo externo do princípio em análise. Os itens seguintes buscam demonstrar algumas consequências da adoção da tese proposta. Ao final, serão enunciadas as conclusões a que se chegou, por meio de proposições objetivas.

\section{Inafastabilidade do controle jurisdicional: regra ou princípio?}

Os juristas costumam referir-se à inafastabilidade do controle jurisdicional como um princípio, ${ }^{12}$ muito embora o façam sem maiores desenvolvimentos teóricos e sem tecer qualquer consideração a respeito das consequências decorrentes desse enquadramento. Diante disso, é imperioso perquirir se é mesmo possível afirmar que a garantia esculpida no art. 5o, XXXV, da Constituição de 1988 tem características de princípio.

Para responder a essa questão cumpre apontar, brevemente, algumas diferenças entre regras e princípios. O objetivo, aqui, não é tratar de forma exaustiva a distinção, que, como se sabe, é objeto de inúmeros e infindáveis estudos e debates. ${ }^{13} \mathrm{O}$ propósito é, apenas, evidenciar algumas diferenças relevantes das duas categorias.

A partir da teoria dos princípios, desenvolvida por Robert Alexy, Virgílio Afonso da Silva chama a atenção para dois aspectos que singularizam princípios e regras: a distinção entre direitos definitivos e direitos prima facie

12 Veja-se, por todos, Frederico Widson da Silva Dantas: “(...) pode-se qualificar o princípio da inafastabilidade como um princípio jurídico constitucional, de natureza processual, que constitui uma das derivações diretas do princípio geral do devido processo legal, notadamente no seu aspecto procedimental (procedural due process), consubstanciando uma das mais importantes garantias constitucionais do processo". Dantas, O princípio constitucional da inafastabilidade, op. cit., p. 83-114. Os títulos dos estudos mencionados na bibliografia deste trabalho corroboram o argumento.

13 As teorias sobre as distinções entre regras e princípios podem ser reunidas em três grupos: (i) teorias que propõem uma distinção forte, que buscam demonstrar que princípios e regras 
e o enquadramento dos princípios como mandados de otimização. No que tange à primeira diferença, o professor da USP enfatiza que:

o principal traço distintivo entre regras e princípios, segundo a teoria dos princípios, é a estrutura dos direitos que essas normas garantem. No caso das regras, garantem-se direitos (ou impõem-se deveres) definitivos, ao passo que, no caso dos princípios, são garantidos direitos (ou são impostos deveres) prima facie. (...) Isso significa que, se um direito é garantido por uma norma que tenha a estrutura de uma regra, esse direito é definitivo e deverá ser realizado totalmente, caso a regra seja aplicável ao caso concreto. (...) No caso dos princípios, não se pode falar em realização sempre total daquilo que a norma exige. Ao contrário: em geral, essa realização é apenas parcial. ${ }^{14}$

Já no que diz respeito ao enquadramento dos princípios como mandados de otimização, Virgílio Afonso da Silva esclarece que a teoria de Robert Alexy parte da premissa de que os princípios jurídicos podem ser realizados em maior ou menor grau, de acordo com as possibilidades fáticas e jurídicas existentes no momento de sua aplicação. Em condições ideais, que não se verificam diante de casos difíceis, devem ser aplicados em sua extensão máxima. ${ }^{15}$

possuem estruturas lógicas e forma de aplicação diversas. São expoentes destas teorias Ronald Dworkin e Robert Alexy; (ii) teorias que propõem uma distinção fraca, que tentam evidenciar que a diferença entre regras e princípios não é qualitativa, mas de grau. Essa é a posição defendida, por exemplo, por Joseph Raz; e (iii) teorias que negam a possibilidade de distinção entre as duas categorias normativas, seja por considerarem que regras e princípios possuem estruturas deônticas idênticas, seja por entenderem que o grau de semelhança entre elas é tão grande que a diferenciação é praticamente impossível. Essa é a tese de Aulis Aarnio. Cf. SILVA, Virgílio Afonso da. A constitucionalização do direito: os direitos fundamentais nas relações entre particulares. São Paulo: Malheiros, 2005. p. 30-32. Para uma análise mais detalhada do tema, veja-se, dentre muitos, ALEXY, Robert. Teoria dos direitos fundamentais. Tradução de Virgílio Afonso da Silva. São Paulo: Malheiros, 2008. p. 85 e ss.; ÁVILA, Humberto. Teoria dos princípios: da definição à aplicação dos princípios jurídicos. 3. ed. São Paulo: Malheiros, 2004; BARCELLOS, Ana Paula de. A eficácia jurídica dos princípios constitucionais: o princípio da dignidade da pessoa humana. Rio de Janeiro: Renovar, 2002. p. 40 e ss. BARCELLOS, Ana Paula de. Ponderação, racionalidade e atividade jurisdicional. Rio de Janeiro: Renovar, 2005, p. 167 e ss.; BARROSO, Luís Roberto. O começo da história. A nova interpretação constitucional e o papel dos princípios no direito brasileiro. In: Temas de direito constitucional. Rio de Janeiro: Renovar, 2005. t. III, p. 3-59. SANCHÍS, Luis Prieto. Diez argumentos a propósito de los principios. In: __. Ley, principios, derechos. Madri: Dykinson, 1998. p. 47-68; e Ronald Dworkin, Levando os direitos a sério, op. cit.

14 SILVA, Virgílio Afonso da. O conteúdo essencial dos direitos fundamentais e a eficácia das normas constitucionais. Revista de Direito do Estado, Rio de Janeiro, a. 1, n. 4, p. 27, out./dez., 2006.

15 Ibid., p. 27. 
Segundo Alexy, a diferença entre essas normas aparece com maior clareza no caso das chamadas colisões de princípios e dos conflitos entre regras. Enquanto um conflito entre regras somente pode ser resolvido por meio (i) de uma cláusula de exceção que elimine o conflito ou (ii) pela declaração da invalidade de uma delas, nas colisões entre princípios, muito embora um deles tenha de ceder, isso não significa que o outro princípio seja inválido ou que haja necessidade de se impor uma cláusula de exceção. No caso das colisões de princípios, um deles terá precedência em face do outro, sob determinadas condições, a depender de seu peso. Desse modo, "conflitos entre regras ocorrem na dimensão da validade, enquanto as colisões entre princípios (...) ocorrem, para além dessa dimensão, na dimensão do peso" ${ }^{16}$ Dworkin, por sua vez, aponta que as regras se aplicam em um modelo de "tudo ou nada", enquanto os princípios possuem uma "dimensão de peso" ${ }^{17}$

Por essas razões, a doutrina sustenta que os direitos fundamentais são positivados, na maioria das vezes, por meio de princípios, e não de regras. Essa é a visão esposada por Jane Reis, ao tratar da questão relativa às restrições a direitos fundamentais. Segundo a autora, é possível inferir uma "cláusula geral de liberdade" de nossa Carta Magna, cujo conteúdo elevaria a critério hermenêutico a percepção de que toda ação estatal que imponha comandos ou proibições configuraria uma limitação a direitos fundamentais. Com isso, Jane Reis interpreta tais comandos como princípios sujeitos à conformação e à restrição, o que seria impossível caso os mesmos fossem tratados como regras. Isto porque o caráter dialético do texto da Constituição de 1988 a qual absorve tanto postulados liberais quanto comunitaristas - , somado às normas extraídas dos dispositivos dos art. 5ํㅜㄴ caput e II, que dão lastro à cláusula geral de liberdade, não permitiriam outra interpretação. ${ }^{18} \mathrm{Na}$ mesma linha, aponta Virgílio Afonso da Silva:

(...) a teoria dos princípios sustenta que, em geral, direitos fundamentais são garantidos por uma norma que consagra um direito prima facie. Como visto (...), o suporte fático dessa norma - que tem a estrutura de princípio - é o mais amplo possível. Isso implica, entre outras coisas, que a colisão com outras normas pode exigir uma restrição à realização

16 Robert Alexy, Teoria dos direitos fundamentais, op. cit., p. 91 e ss.

17 Ronald Dworkin, Levando os direitos a sério, op. cit., p. 25 e ss.

18 PEREIRA, Jane Reis Gonçalves. Aspectos gerais sobre a restrição de direitos fundamentais. Disponível em: <http://works.bepress.com/cgi/viewcontent.cgi?article=1007\&context=janere is>. Acesso em: 1ํo out. 2014. 
desse princípio. Essas normas constituem, portanto, as restrições ao direito fundamental garantido pelo princípio em questão. ${ }^{19-20}$

Observe-se, ainda, que, embora o enunciado do art. 5ㅇ, XXXV, da Constituição esteja redigido em termos categóricos, esse fato não autoriza a conclusão de que se estaria diante de uma regra, e não de um princípio. É importante, nesse sentido, não confundir dispositivos (ou enunciados) com as normas de direitos fundamentais. É o que salienta, com acerto, Oscar Vilhena Vieira:

As Constituições são compostas por dispositivos com pretensão prescritiva, ou seja, enunciados que pretendem determinar condutas. Não devemos confundir estes dispositivos ou enunciados com as próprias normas de direitos fundamentais, como nos alerta Alexy. Quando lemos o enunciado do art. 5o, IV, da CF - "é livre a manifestação do pensamento, sendo vedado o anonimato" - devemos tentar compreender qual é a prescrição derivada desse enunciado, ou seja, qual a proibição ou obrigação prescrita pelo enunciado. Assim, poderíamos dizer que a norma expressa por esse enunciado é que "o Estado encontra-se proibido de impedir alguém de manifestar seu pensamento", ou que "as pessoas encontram-se autorizadas a manifestar seu pensamento sem que sejam censuradas pelo Estado". O elemento normativo (proibição, autorização ou obrigação) nem sempre se encontra claro no enunciado. Isso ocorre com grande incidência na esfera dos direitos fundamentais. ${ }^{21}$

O enunciado do art. 5으, XXXV, da CRFB não garante aos particulares o direito de reivindicar, perante o Poder Judiciário, a proteção a todo e qualquer problema que tenham. Também não impõe deveres definitivos de atuação ao Estado. Em verdade, o dispositivo estabelece direitos e garantias prima facie, que podem ceder à luz de outros direitos fundamentais. O Poder Judiciário

19 Virgílio Afonso da Silva, O conteúdo essencial dos direitos fundamentais e a eficácia das normas constitucionais, op. cit., p. 39.

20 Em sentido ligeiramente diverso, Gilmar Mendes salienta que "no âmbito dos direitos fundamentais, (...), normas que configuram princípios são mais frequentes". MENDES, Gilmar Ferreira; COELHO, Inocêncio Mártires; BRANCO, Paulo Gustavo Gonet. Curso de direito constitucional. São Paulo: Saraiva, 2007. p. 274.

21 VIEIRA, Oscar Vilhena. Direitos Fundamentais: uma leitura da jurisprudência do STF. São Paulo: Malheiros, 2006. p. 52-53. 
só estará obrigado a atuar em circunstâncias específicas. Tanto que se exige o preenchimento de determinadas condições para o exercício do direito de ação. E isso não viola o princípio da inafastabilidade do controle jurisdicional.

Por trás de seus termos categóricos, o art. 5ํ, XXXV, da Constituição busca proibir que o Estado-Juiz se abstenha de decidir a generalidade das questões que lhe são submetidas. Mas isso não significa que ele deva, necessariamente, decidir todas as questões, substituindo-se à vontade das partes. Há questões que não estão sujeitas a intervenção judicial (questões políticas, por exemplo) e outras em relação às quais as partes podem dispor como bem entenderem (em diversas matérias patrimoniais, v.g.) e, inclusive, recorrer a métodos alternativos de solução de conflitos, que afastam a possibilidade de o EstadoJuiz arbitrar ou decidir a matéria.

Em outras palavras, a intervenção judicial é obrigatória de acordo com as circunstâncias fáticas e jurídicas subjacentes. A inafastabilidade do controle jurisdicional deve ser assegurada tanto quanto possível, mas pode ceder a outros valores (como autonomia da vontade, por exemplo, no caso da arbitragem) igualmente fundamentais.

À luz dessas considerações, não há dúvidas de que a garantia fundamental da inafastabilidade do controle jurisdicional tem natureza principiológica. Trata-se, inequivocamente, de princípio que deve ser aplicado na medida de suas possibilidades fáticas e jurídicas. Nesse sentido, é possível identificar uma clara evolução do conceito de tutela jurisdicional. É o que ressalta, com absoluta propriedade, Flavio Galdino:

(...) o conceito em questão [tutela jurisdicional] é produto de maturação teórica, tendo sido desenvolvido a partir do (i) princípio da ubiquidade da jurisdição, passando pelo (ii) princípio da garantia do direito de ação, pelo (iii) princípio da inafastabilidade do controle jurisdicional, tornando-se um (iv) princípio do acesso à justiça e, quase concomitantemente, referido como (v) princípio da tutela jurisdicional adequada. $^{22}$

Na visão do mencionado autor, em sua primeira fase evolutiva, enquanto princípio da ubiquidade da jurisdição, a garantia da tutela jurisdicional

22 GALDINO, Flávio. A evolução das ideias de acesso à justiça. In: SARMENTO, Daniel; GALDINO, Flávio (Org.). Direitos fundamentais: estudos em homenagem ao professor Ricardo Lobo Torres. Rio de Janeiro: Renovar, 2006. p. 435. 
representava (i) uma resposta aos abusos do Poder Executivo, cuidando preponderantemente da relação entre os poderes; (ii) tinha por escopo preservar a separação e o equilíbrio entre os poderes; (iii) era dirigida ao legislador e não ao juiz; e, portanto, era uma regra externa ao procedimento.

$\mathrm{Na}$ fase seguinte, desenvolvem-se novos instrumentos processuais, como a ação e institutos afins, e desses direitos derivam garantias essenciais do processo. Na terceira fase (princípio da inafastabilidade do controle jurisdicional): além das três características iniciais, o princípio incorpora em seu conceito "as garantias essenciais do processo (contraditório, motivação etc.)". Posteriormente, há:

uma substancial mutação conceitual, de modo que o direito de acesso à justiça: (i) tem como base as ideias de isonomia material e efetividade do processo; (ii) contempla a relação processual propriamente dita e não as relações entre o Poder Judiciário e os demais poderes; (iii) está dirigido à efetividade da tutela jurisdicional, que passa a ocupar lugar de centralidade na teoria jurídica processual; (iv) ainda assim, permanece dirigido fundamentalmente ao legislador; (v) promove a implementação de meios alternativos de solução de controvérsias.

Em sua última etapa evolutiva, a qual ainda não está plenamente consolidada, a ideia central passa a ser a de assegurar tutela jurisdicional adequada:

tem-se então o princípio da tutela jurisdicional adequada como: (i) lastreado em um direito à efetividade entendido de forma extremamente abrangente; (ii) voltado para as situações jurídicas das partes no processo (internas ao processo); (iii) e, portanto, dirigido ao juiz. ${ }^{23}$

Essa evolução do conceito comprova, em nossa visão, que a incidência do princípio da inafastabilidade do controle jurisdicional depende das condições fáticas e jurídicas subjacentes a cada momento histórico.

23 Flávio Galdino, A evolução das ideias de acesso à justiça, op. cit., p. 434-458. 


\section{3. Âmbito de proteção do princípio}

Evidenciada a natureza principiológica da garantia da inafastabilidade do controle jurisdicional, cumpre analisar seu âmbito de proteção. Para identificálo, segundo Virgílio Afonso da Silva, deve-se indagar "que atos, fatos, estados ou posições jurídicas são protegidos pela norma que garante o referido direito" ${ }^{24}$ Quanto maior for o âmbito de proteção de um direito fundamental, maiores o potencial de colisão com outros direitos e a necessidade de recurso à técnica da ponderação para a solução do conflito.

No caso da inafastabilidade do controle jurisdicional, não é trivial a identificação do âmbito de proteção da norma. Com efeito, o art. 5ํㅜ, XXXV, da CRFB não deixa clara a extensão de sua proteção, e as hipóteses em que a formulação de exigências legais representa violação à garantia. Em verdade, a norma é bem aberta e confere ao legislador ampla margem de conformação.

Em outras palavras, o âmbito de proteção do princípio da inafastabilidade do controle jurisdicional é normativo. O efetivo exercício do direito depende de um processo de conformação legislativa, por meio da edição de leis que permitam o gozo desse direito. Cabe, pois, ao legislador ordinário o importante papel de viabilizar o exercício desse direito, por meio da definição de procedimentos, ritos, ações, recursos, competências etc. O legislador, no entanto, não pode desnaturar o instituto, sob pena de violá-lo. Veja-se, a propósito, a lição de Gilmar Mendes, Inocêncio Mártires Coelho e Paulo Gustavo Gonet Branco:

Certos direitos individuais, como o direito de propriedade e o direito à proteção judiciária, são dotados de âmbito de proteção estritamente normativo (...). Nesses casos, não se limita o legislador ordinário a estabelecer restrições a eventual direito, cabendo-lhe definir, em determinada medida, a amplitude e a conformação desses direitos individuais. Acentue-se que o poder de conformar não se confunde com uma faculdade ilimitada de disposição. ${ }^{25}$

24 SILVA, Virgílio Afonso da. Direitos fundamentais: conteúdo essencial, restrições e eficácia. 2. ed., 2. tir. São Paulo: Malheiros, 2011. p. 72.

25 Gilmar Mendes, Inocêncio Mártires Coelho e Paulo Gustavo Gonet Branco, Curso de direito constitucional, op. cit., p. 285. 
Como o âmbito de proteção judicial é inequivocamente normativo, não há dúvida de que as providências básicas que se desenvolvam têm por escopo conferir conformação a esse direito. Evidente que o exercício do direito de proteção judicial efetiva pressupõe a existência de tribunais, a definição de competências e a definição dos procedimentos a serem adotados. Daí afirmar-se correntemente o caráter de garantia institucional desse direito, o que não autoriza, porém, concluir que semelhante garantia depende exclusivamente da atividade legislativa ordinária ou que qualquer decisão do legislador configura concretização do direito à proteção judicial efetiva. (...) Qualquer que seja a conclusão a propósito do caráter de mera conformação ou limitação, não pode o legislador, a pretexto de conformar ou disciplinar a garantia da proteção judicial efetiva, adotar disciplina que afete, de forma direta ou indireta, o exercício substancial desse direito. ${ }^{26}$

Assim, em relação aos princípios que têm âmbito de proteção normativo, como é o caso da inafastabilidade do controle jurisdicional, embora o legislador possa delinear os requisitos para o exercício desses direitos, e isso possa, em alguma medida, restringir sua amplitude, isso não lhe confere o poder de desvirtuar ou desnaturar a proteção assegurada. Apesar de a intervenção legislativa ser necessária, é vedada qualquer restrição que, por sua profundidade, possa afetar ou comprometer a proteção judicial efetiva. Há um limite para a atividade conformadora e restritiva dos direitos fundamentais, que é o seu núcleo essencial (limite dos limites). ${ }^{27}$

Diante disso, é importante investigar se o non liquet pode ser considerado um desvirtuamento do âmbito de proteção ou uma agressão ao núcleo essencial do princípio da inafastabilidade do controle jurisdicional. Para isso, é importante expor, rapidamente, as teorias sobre o núcleo essencial, a fim de permitir a identificação do seu conteúdo.

\section{Teorias a respeito da proteção do núcleo essencial}

Conforme leciona Jorge Reis Novais, o surgimento da teoria da proteção ao núcleo essencial dos direitos está diretamente relacionado à Constituição

26 Ibid., p. 492-493.

27 O desvirtuamento do instituto equipara-se à agressão ao núcleo essencial. 
de Weimar e ao surgimento das normas programáticas, como mecanismo para restringir a atividade do legislador. No entanto, a teoria ganha novos contornos com a Lei Fundamental de Bonn, como um esforço de atribuição de um sentido mínimo aos direitos fundamentais. Veja-se:

(...) em Weimar, o apelo à preservação do núcleo essencial dos direitos fundamentais constituía uma tentativa de limitar, de algum modo, a margem de que dispunha o legislador. (...) a consagração da garantia do conteúdo essencial surge, diferentemente, na Lei Fundamental de Bona, ligada a esse esforço de atribuição de um sentido constitucional efectivo aos direitos fundamentais. (...) No novo contexto do Estado constitucional do pós-guerra, a garantia do conteúdo essencial procuraria desempenhar, tendencialmente, o papel de garantia plena dos direitos fundamentais (....). ${ }^{28}$

A ideia de se proteger o núcleo essencial dos direitos fundamentais, embora seja uma criação alemã (positivada no art. 19, nํ2, da Lei Fundamental de Bonn), ${ }^{29}$ encontrou acolhida em outros países. Portugal e Espanha, por exemplo, incluíram em suas Constituições cláusulas determinando a preservação do núcleo essencial como limite dos limites à restrição de direitos fundamentais (Cf., respectivamente, o art. 18, no 3, ${ }^{30}$ da Constituição portuguesa, e o art. 53, no 1 , da Constituição espanhola). ${ }^{31}$

No Brasil, embora não haja previsão expressa, tanto a doutrina quanto a jurisprudência vêm afirmando que os direitos fundamentais não podem ser restringidos a ponto de esvaziar a proteção assegurada pela Constituição. ${ }^{32}$

28 NOVAIS, Jorge Reis. As restrições aos direitos fundamentais não expressamente autorizadas pela Constituição. Coimbra: Coimbra, 2003. p. 779.

29 Constituição alemã, art. 19: “2. Em nenhum caso, um direito fundamental poderá ser violado em sua essência". Disponível em: <www.brasil.diplo.de/contentblob/3160404/Daten/1330556/ Gundgesetz_pt.pdf>. Acesso em: 5 abr. 2014.

30 Constituição portuguesa, art. 18: “3. As leis restritivas de direitos, liberdades e garantias têm de revestir caráter geral e abstracto e não podem ter efeito retroativo nem diminuir a extensão e o alcance do conteúdo essencial dos preceitos constitucionais". Disponível em: <www. parlamento.pt/Legislacao/Paginas/Constituicao RepublicaPortuguesa.aspx $>$. Acesso em: 5 abr. 2014

31 Constituição espanhola, art. 53: "1. Los derechos y libertades reconocidos en el Capítulo segundo del presente Titulo vinculan a todos los poderes publicos. Sólo por ley, que en todo caso deberá respetar su contenido esencial, podrá regularse el ejercicio de tales derechos y libertades que se tutelarán de acuerdo con lo previsto en el artículo 161, 1, a." Disponível em: <www.senado.es/web/conocersenado/ normas/constitucion/index.html>. Acesso em: 4 abr. 2014.

32 Na doutrina, veja-se, por todos, Virgílio Afonso da Silva, Direitos fundamentais, op. cit., p. 26 e ss. Na jurisprudência, confira-se o voto proferido pelo min. Celso de Mello no julgamento 
A grande dificuldade de operar com o conceito de núcleo essencial envolve a sua identificação. Para auxiliar o operador do direito a identificá-lo surgiram algumas teorias: absolutas, relativas, subjetivas, objetivas e mistas. ${ }^{33}$ Interessam aos propósitos deste estudo, especialmente, as teorias absoluta e relativa, que serão apresentadas resumidamente a seguir.

\subsection{Teorias absolutas ou do núcleo duro}

Os defensores das teorias absolutas - também denominadas de teorias do núcleo duro -, conforme leciona Ana Paula de Barcellos, sustentam que o núcleo dos direitos fundamentais não pode ser objeto de restrições ou relativizações sob qualquer conjuntura. Tal conteúdo encontraria suas limitações em um plano abstrato. Desse modo, previamente ao processo de ponderação, o intérprete já conheceria os aspectos dos direitos envolvidos na colisão que não poderiam, de forma alguma, ser objeto de restrições. Haveria, portanto, um limite prévio ao próprio processo de ponderação. ${ }^{34}$ Como bem explica Jorge Reis Novais:

a teoria absoluta (...) entende o conteúdo essencial como grandeza estática e intemporal. (...) considera que há, em cada direito fundamental, uma zona, esfera ou âmbito nuclear intocável que, sob pena de desnaturação ou perda do seu sentido útil, em caso algum poderá ser afectada. ${ }^{35}$

Em que pesem seus louváveis propósitos, as teorias absolutas pecam pela dificuldade de identificação, prima facie, daquilo que não pode ser objeto de qualquer restrição. Não é tarefa fácil - e muitos afirmam que

do HC no 82.424/RS, rel. min. Moreira Alves, rel. p/acórdão, min. Maurício Côrrea, Tribunal Pleno, j. em 17.9.03, DJe de 19.3.04, p. 17.

33 Para uma análise aprofundada da discussão sobre o núcleo essencial dos direitos fundamentais, vejam-se os seguintes estudos: Jorge Reis Novais, As restrições aos direitos fundamentais não expressamente autorizadas pela Constituição, op. cit., p. 779 e ss.; Anna Paula de Barcellos, Ponderação, racionalidade e atividade jurisdicional, op. cit., p. 139-146; e PEREIRA, Jane Reis Gonçalves. Interpretação constitucional e direitos fundamentais: uma contribuição ao estudo das restrições aos direitos fundamentais na perspectiva da teoria dos princípios. Rio de Janeiro: Renovar, 2006. p. 297-366.

34 Ana Paula de Barcellos, Ponderação, racionalidade e atividade jurisdicional, op. cit., p. 143.

35 Jorge Reis Novais, As restrições aos direitos fundamentais não expressamente autorizadas pela Constituição, op. cit., p. 782. 
seria mesmo impossível - identificar, de antemão, restrições inadmissíveis, antes de confrontar os direitos fundamentais subjacentes, em um processo de ponderação. E nisso reside a diferença dessas teorias.

\subsection{Teorias relativas ou do núcleo flexivel}

Os adeptos das teorias relativas - ou do núcleo flexível - consideram que o núcleo essencial só pode ser identificado após o processo de ponderação. Para eles, não há conteúdo em abstrato que não possa sofrer restrições. $\mathrm{O}$ conteúdo mínimo dos direitos só pode ser identificado à luz das circunstâncias fáticas e jurídicas subjacentes. ${ }^{36}$ Para os defensores dessa corrente,

não é a gravidade ou intensidade da lesão, a relevância da justificação ou o tipo de prejuízo na liberdade que determinam, por si só, a ativação da garantia do conteúdo essencial. O que está em causa é, antes, a natureza da relação que se estabelece entre os bens em confronto e entre o fim prosseguido com a restrição e o meio utilizado, considerandose que há violação ao conteúdo essencial dos direitos fundamentais quando se verifica um excesso, uma desproporcionalidade, uma desnecessidade, independentemente do muito ou pouco que reste do direito fundamental após a incidência da restrição. (...) para a teoria relativa, a garantia do conteúdo essencial se identifica com o princípio da proibição do excesso num quadro de ponderação de bens. ${ }^{37}$

O fato de que o núcleo essencial só poderia ser identificado - e restringido - após a avaliação e a ponderação dos direitos colidentes traz algumas implicações importantes. Se, por um lado, torna mais fácil, em certa medida, a demonstração do conteúdo mínimo de cada direito, também faz, por outro, com que o conteúdo essencial de um mesmo direito possa variar, em casos diversos, em razão das circunstâncias subjacentes. Em outras palavras, para os adeptos da teoria relativa, por exemplo, uma restrição legislativa severa pode

36 TORRES, Ricardo Lobo. O mínimo existencial como conteúdo essencial dos direitos fundamentais. In:___. Direitos sociais: fundamentos, judicialização e direitos sociais em espécie. Rio de Janeiro: Lumen Juris, 2010. p. 320.

37 Jorge Reis Novais, As restrições aos direitos fundamentais não expressamente autorizadas pela Constituiçãao, op. cit., p. 781. 
ser tida como inadmissível por violação à livre-iniciativa, mas ser tolerada, em outro caso, à luz do direito fundamental que promove. ${ }^{38}$

\subsection{Críticas às teorias absolutas e relativas}

Como já decorre do quanto exposto até aqui, nenhuma das duas teorias é imune a críticas. De um lado, é possível questionar a teoria absoluta ao argumento de que é praticamente impossível identificar os contornos do núcleo essencial do direito fundamental em abstrato. Há, ainda, o risco - real - de que a ideia de núcleo duro desvalorize os elementos externos, diminuindo a esfera de proteção do direito. Ademais, a doutrina questiona a operacionalidade da teoria, diante da constatação de que, em muitos casos, um direito fundamental deverá ceder totalmente a outro. ${ }^{39}$ Nesse sentido, defendendo a teoria relativa, Daniel Sarmento afirma que, nas teorias absolutas,

questões concretas podem afetar ao mesmo tempo o cerne de dois direitos fundamentais contrapostos, levando o juiz ao dilema de ter de optar por um deles em detrimento do outro. Para casos desta espécie, a teoria absoluta cria uma situação insustentável para o julgador, que, se não a flexibilizar, é forçado a proferir um non liquet. ${ }^{40}$

Por outro lado, a importância e a validade das teorias relativas também podem ser colocadas em xeque, tendo em vista que, nesse caso, o núcleo do direito fundamental acabaria por se confundir com o próprio resultado da ponderação. ${ }^{41}$ Embora o núcleo duro devesse servir de limite à atividade

38 Virgílio Afonso da Silva, O conteúdo essencial dos direitos fundamentais e a eficácia das normas constitucionais, op. cit., p. 42.

39 Jorge Reis Novais, As restrições aos direitos fundamentais não expressamente autorizadas pela Constituição, op. cit., p. 783.

40 SARMENTO, Daniel. A ponderação de interesses na Constituição Federal. Rio de Janeiro: Lumen Juris, 2000. p. 112-113.

41 Conforme ensina Jorge Miranda: "Afigura-se que para, realmente, funcionar como barreira última e efectiva contra o abuso do poder, como barreira que o legislador, seja qual for o interesse (permanente ou conjuntural) que prossiga, não deve romper, o conteúdo essencial tem de ser entendido como um limite absoluto correspondente à finalidade ou ao valor que justifica o direito. As teses relativistas são de rejeitar, porque confundem proporcionalidade

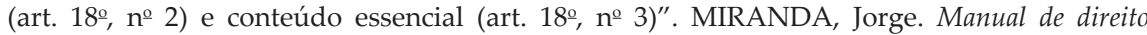
constitucional, Tomo IV: Direitos fundamentais. 3. ed. Coimbra: Coimbra, 2000. Virgílio Afonso da Silva responde diretamente essa crítica dizendo que: “Não é o que as teorias relativistas fazem [essa confusão]. Como mencionado acima, as teorias que pressupõem um conteúdo 
ponderativa do direito fundamental, ela seria seu resultado. Nesse sentido, o conteúdo essencial do direito fundamental mostrar-se-ia incapaz de servir de bússola ou norte para a atividade de conformação e restrição de direitos fundamentais. ${ }^{42}$ Além disso, as teorias relativas deixam o direito desprotegido, tendo em vista que

tanto se poderia considerar violado [o conteúdo essencial] por uma intervenção insignificante que só superficialmente restringisse o direito fundamental, como se poderia considerar incólume perante uma restrição gravíssima que afectasse fortemente o direito; tudo dependia, não da gravidade da restrição, mas da respectiva proporcionalidade. ${ }^{43}$

Apesar das críticas que ambas as teorias suscitam, o núcleo essencial teria pouca ou nenhuma valia como limite dos limites caso adotássemos a teoria relativa. Nesse sentido, aderimos à teoria absoluta, com os temperamentos propostos pela professora Ana Paula de Barcellos. ${ }^{44}$

A referida professora sustenta, com acerto, que o núcleo dos direitos fundamentais não pode ser delineado de forma absoluta e permanente. ${ }^{45}$

essencial relativo identificam esse núcleo com o produto da regra da proporcionalidade. Ou seja, tratam a essencialidade como um valor a ser respeitado no caso concreto". Virgílio Afonso da Silva, Direitos fundamentais, op. cit., p. 198.

42 Ana Paula de Barcellos, Ponderação, racionalidade e atividade jurisdicional, op. cit., p. 143-144.

43 Jorge Reis Novais, As restrições aos direitos fundamentais não expressamente autorizadas pela Constituição, op. cit., p. 783.

44 Também chamada por Virgílio Afonso da Silva de "Teoria do Conteúdo Essencial AbsolutoDinâmico". Virgílio Afonso da Silva, Direitos fundamentais, op. cit., p. 188.

45 Em sentido semelhante ao defendido por Ana Paula de Barcellos, na doutrina espanhola: " $\mathrm{La}$ garantía de que existe un mínimo contenido de cada derecho que no puede ser relativizado ni anulado, pese a que la Constitución no lo defina expresamente. La garantía, por tanto, de que cada derecho, ya no puede ser definido generalmente de una manera estática y aislada, sino de una manera dinámica y relacional, esto es, en su relación con otros derechos constitucionales, debe conservar su sustantividad en esa definición dinámica y relacional que del mismo modo debe realizarse". CALLEJÓN, Francisco Balaguer et al. Manual de derecho constitucional. Madri: Grupo Anaya-Tecnos, 1990. p. 170. Em uma posição independente: "Tal y como aparece formulada en la doctrina, la teoría absoluta conduce inevitablemente al conflicto y a la jerarquización entre derecho fundamentales, o entre éstos y los bienes colectivos, como suceden en el caso de la prisión perpetua y los bienes que ella pretende realizar o preservar frente al derecho a la libertad ambulatoria. La teoría relativa no comporta tales consecuencias, pero ello acontece al precio del debilitamiento completo del derecho, que se convierte en mero derecho prima facie. En ambos casos, derecho y garantía aparecen fuertemente relativizados y se admite, con distintos grados, la restricción del derecho por límites externos. (...) Identificamos, pues, contenido esencial con contenido del derecho, prescindiendo de núcleos duros y periferias disponibles, e introducimos el requisito del ajustamiento como parte del proceso de determinación del contenido esencial. (...)Puede entonces plantearse cuál es la diferencia entre lo propuesto aquí y la teoría relativa. La respuesta es la siguiente: esta teoría no insiste lo suficiente en la delimitación positiva del contenido esencial. Para ella, la restricción al derecho está justificada si la medida supera con éxito el test de 
No entanto, isso não significa que a doutrina e a jurisprudência não possam construir parâmetros para nortear a identificação das hipóteses em que há violação do núcleo essencial. Nas palavras da ilustre professora:

(...) parece realmente impossível (e mesmo inconveniente) que se possa delinear esse núcleo de forma absoluta - "dura" - e permanente, como se fosse humanamente viável formular um juízo "all things considered", capaz de antever e considerar todos os elementos relevantes, ou como se o sentido dos conceitos jurídicos não variasse em função da compreensão histórica dos fenômenos sociais. O que se acaba de registrar, porém, não significa que a impossibilidade de atingir o ideal das teorias absolutas condene o intérprete e os jurisdicionados às teorias flexíveis ou relativas. É perfeitamente possível e desejável, por meio da reflexão abstrata e/ou do estudo e tabulação dos precedentes judiciais, que a doutrina se ocupe de construir os sentidos próprios de cada direito, propondo parâmetros ou standards, específicos capazes de identificar o que deve ser considerado como prerrogativa essencial de cada direito, o que pode sofrer restrição, em que circunstâncias isso pode acontecer, dentre outros elementos necessários para a compreensão mais precisa dos direitos. ${ }^{46}$

A identificação do núcleo essencial de um princípio tem importância ímpar para a teoria absoluta, na medida em que seu conteúdo é irrestringível e imponderável, atuando, desse modo, como regra jurídica, aplicável mediante processo de subsunção. Apenas a parte mais externa do princípio, que não se identifica com seu núcleo, é passível de ponderação e se aplica na medida de suas possibilidades fáticas e jurídicas. ${ }^{47}$ Nesse sentido: "Para a teoria absoluta

proporcionalidad. Parte, pues, de la actividad limitadora del derecho, y la garantía del contenido esencial funciona como límite de los límites constitucionalmente admisibles. Por el contrario, en la propuesta que se desarrollará a continuación, el contenido esencial se delimita desde el bien humano protegido por el derecho, esto es, desde la finalidad del derecho mismo. Lo que sucede es que, en virtud del concepto de bien humano y de derecho que aquí se va a sostener, éstos incluyen necesariamente, para ser tales, la armonización y el ajustamiento - no restricción - con otros bienes igualmente humanos y con otras pretensiones igualmente dignas de convertirse en derechos." SERNA, Pedro; TOLLER, Fernando M. La interpretación constitucional de los derechos fundamentales: una alternativa a los conflictos de derechos. Buenos Aires: La Ley, 2000. p. 44-56.

46 Ana Paula de Barcellos, Ponderação, racionalidade e atividade jurisdicional, op. cit., p. 144-145.

47 Nesse sentido, Barcellos (ibid., p. 180) leciona que "os princípios (...) operam na realidade de duas formas distintas: relativamente ao seu núcleo, funcionam como regras e, apenas em relação a sua área não nuclear, funcionam como princípios propriamente ditos". 
existe um núcleo de cada direito fundamental que em nenhum caso pode ser objeto de intervenção nem se sujeita à ponderação. Se as normas de direito fundamental não podem ser ponderadas, é porque representam regras". ${ }^{48}$

Diante disso, é importante identificar os contornos do núcleo essencial do princípio da inafastabilidade do controle jurisdicional. Afinal, como se disse, esse núcleo não poderá ser ponderado; deverá ser aplicado como regra. É isso o que se pretende com o tópico que se segue.

\section{Identificando o núcleo essencial do princípio da inafastabilidade do controle jurisdicional}

Impõe-se, neste passo, a difícil tarefa de identificar o núcleo essencial e o halo externo do princípio da inafastabilidade do controle jurisdicional, com o objetivo de apurar quando ele deverá incidir como regra e quando será possível ponderá-lo.

Inicialmente, é importante observar que, tratando-se de princípio cujo âmbito de proteção é normativo, tem-se, como enfatizado anteriormente, que a sua conformação depende de um atuar legislativo. Isso significa que a violação ao núcleo essencial pode ocorrer tanto por ação quanto por omissão.

Sob o prisma da omissão, ocorrerá violação ao núcleo essencial na eventual hipótese de ausência absoluta de instrumentos jurídicos aptos a proteger um direito contra lesão ou ameaça a direito. Nessas circunstâncias, pode o Poder Judiciário, mesmo não havendo lei que o autorize a tanto, atuar na proteção do direito, sem que isso represente violação à separação de poderes. Em que pese não vigorar mais, no ordenamento jurídico, dispositivo como o do art. 75 do Código Civil de 1916, o qual estabelecia que "a todo direito corresponde uma ação, que o assegura", por incidência direta e imediata do princípio da inafastabilidade do controle jurisdicional, os juízes podem, em situações extremas, excepcionais, atuar para defender direitos contra lesão ou ameaça. É legítima, nesse sentido, a concessão de ordem, em Mandado de Injunção, para assegurar o exercício e a proteção de direitos contra omissões inconstitucionais do poder público e do legislador, como, aliás, vem reconhecendo, mais recentemente, o Supremo Tribunal Federal..$^{49}$

48 Ricardo Lobo Torres, O mínimo existencial como conteúdo essencial dos direitos fundamentais, op. cit., p. 320.

49 Nesse sentido, os acórdãos dos STF, MI 712/PA rel. min. Eros Grau, Tribunal Pleno, j. em 25/10/2007, DJe 23/11/2007; STF, MI 670/ES rel. min. Mauricio Corrêa, rel. p/ Acordão min. 
Mas não só nessas hipóteses se configura a violação ao núcleo essencial. Mesmo quando tenha editado lei, o legislador poderá incorrer em violação ao princípio da inafastabilidade do controle jurisdicional quando haja instituído proteção insuficiente (omissão parcial), bem assim quando houver restringido, demasiadamente, o acesso ao Poder Judiciário. Nesse sentido, questionou-se, no passado, a constitucionalidade da lei de arbitragem (Lei no 9.307/1996), ao argumento de que ela violaria o princípio da inafastabilidade do controle jurisdicional, por impedir a parte que aderiu voluntariamente à arbitragem de recorrer à Justiça para discutir a mesma questão. Também se questionou, no passado, a constitucionalidade do art. 4º da Lei nº 9.494/1997, que vedou a concessão de liminares contra a fazenda pública. Em ambos os casos, o STF entendeu que tais restrições não violavam o art., 5o, XXXV, da Constituição, ${ }^{50}$ isto é, que não atingiam o núcleo essencial do princípio da inafastabilidade do controle jurisdicional. Com isso, em autêntica ponderação de princípios, o STF acabou por concluir que tais hipóteses se situavam no halo externo do princípio, fora, portanto, da área nuclear.

Gilmar Mendes, Tribunal Pleno, j. em 25/10/2007, DJe 6/11/2007; e STF, MI 708/PA rel. min. Gilmar Mendes, Tribunal Pleno, j. em 25/10/2007, DJe 6/11/2007; que aplicaram analogicamente, no que coubesse, as Leis Federais no 7.701/1988 e n⿳o 7.783/1989, para viabilizar o exercício do direito de greve pelos servidores públicos (CF art. 37, VII), após 20 anos de mora do legislador ordinário para legislar sobre o tema.

50 No caso da Lei de Arbitragem (Lei no 9.307/1996), o Tribunal decidiu, por maioria, pela constitucionalidade da cláusula compromissória, in verbis: “(...) 3. Lei de Arbitragem (L. 9.307/96): constitucionalidade, em tese, do juízo arbitral; discussão incidental da constitucionalidade de vários dos tópicos da nova lei, especialmente acerca da compatibilidade, ou não, entre a execução judicial específica para a solução de futuros conflitos da cláusula compromissória e a garantia constitucional da universalidade da jurisdição do Poder Judiciário (CF, art. 5o, XXXV). Constitucionalidade declarada pelo plenário, considerando o Tribunal, por maioria de votos, que a manifestação de vontade da parte na cláusula compromissória, quando da celebração do contrato, e a permissão legal dada ao juiz para que substitua a vontade da parte recalcitrante em firmar o compromisso não ofendem o artigo $5^{\circ}, \mathrm{XXXV}$, da CF. Votos vencidos, em parte - incluído o do relator - que entendiam inconstitucionais a cláusula compromissória - dada a indeterminação de seu objeto - e a possibilidade de a outra parte, havendo resistência quanto à instituição da arbitragem, recorrer ao Poder Judiciário para compelir a parte recalcitrante a firmar o compromisso, e, consequentemente, declaravam a inconstitucionalidade de dispositivos da Lei 9.307/96 (art. 6º parág. único; 7ํ e seus parágrafos e, no art. 41, das novas redações atribuídas ao art. 267, VII e art. 301, inciso IX do C. Pr. Civil; e art. 42), por violação da garantia da universalidade da jurisdição do Poder Judiciário. Constitucionalidade - aí por decisão unânime, dos dispositivos da Lei de Arbitragem que prescrevem a irrecorribilidade (art. 18) e os efeitos de decisão judiciária da sentença arbitral (art. 31)". (STF, SEC 5.206 AgR rel. min. Sepúlveda Pertence, Tribunal Pleno, j. em 12/12/2001, DJe 19/12/2001). No caso da Lei no 9.494, v. acórdão do STF ADC 4 MC rel. min. Sydney Sanches, Tribunal Pleno. j. em 11/2/1998, DJe 13/2/1998. 
Em verdade, o STF nunca ${ }^{51}$ declarou a inconstitucionalidade de uma lei por violação ao princípio da inafastabilidade da tutela jurisdicional, de modo que não há como recorrer à jurisprudência para definir parâmetros do que vem a ser o núcleo duro do princípio. Aquela Corte Constitucional só tem se valido do princípio para reconhecer a inconstitucionalidade de decisões proferidas por tribunais inferiores, que se recusaram a analisar determinada causa, o que se mostra consentâneo com o entendimento aqui esposado.

Desse modo, diante da ausência de standards judiciais, que possam nortear a configuração do núcleo essencial e do halo externo do princípio, passamos a apresentar algumas contribuições.

Em nossa compreensão, a proteção conferida, prima facie, pelo princípio da inafastabilidade do controle jurisdicional deve incidir verticalmente, com mais força e vinculação nos primeiros graus de jurisdição, nas instâncias ordinárias. Essa vinculação deve ser atenuada nas instâncias superiores, de modo que podem ser afastados ou limitados os recursos cabíveis contra decisões proferidas pelo juízo natural. Em outras palavras, o núcleo essencial do princípio, que ostenta a característica de regra e é, por essa razão, imponderável, situa-se perante o juiz natural da causa que, em regra, se dá no primeiro grau de jurisdição, ${ }^{52}$ ao passo que seu halo mais externo, o qual é, por sua natureza, ponderável, identifica-se com os Tribunais Superiores. Por isso, o princípio deve incidir de forma vertical sobre os diferentes graus de jurisdição, impondo distintos níveis de concretização.

Tal conclusão parece inevitável diante das realidades jurídica e judiciária que se apresentam e dos próprios paradigmas da teoria do direito. Na esteira da discussão já travada anteriormente, o princípio da inafastabilidade deve

51 Além disso, em grande parte dos julgados da Corte, há uma clara identificação entre a inafastabilidade do controle jurisdicional e os limites impostos pela legislação processual. Nesse sentido, confira-se o seguinte julgado: ARE 794653 ED/SP, rel. min. Luís Roberto Barroso, Primeira Turma, j. em 13/5/2014, DJe 10/06/2014: “Não foram ofendidas as garantias da inafastabilidade do controle jurisdicional, do devido processo legal, do contraditório e da ampla defesa, pois a parte recorrente teve acesso a todos os meios de impugnação previstos na legislação processual, havendo o acórdão recorrido examinado todos os argumentos e motivado suas conclusões de forma satisfatória. Embargos de declaração recebidos como agravo regimental a que se nega provimento". No mesmo sentido: ARE $799192 \mathrm{AgR} / \mathrm{RS}$ min. Luiz Fux, Primeira Turma j. em 13/5/2014, DJe 29/5/2014; STF AI 673923 AgR/Rj rel. min. Ayres Britto, Segunda Turma, j. em 6/3/2012, DJe 4/5/2012.

52 O mesmo raciocínio se aplica aos casos em que a Constituição estabeleceu competência originária de um tribunal. Nessa hipótese, a lei não poderá afastar a apreciação da matéria e não serão admissíveis juízos de non liquet. $\mathrm{O}$ argumento não se aplica aos processos objetivos, mas, apenas, aos processos subjetivos. 
garantir, em seu núcleo, que o cidadão tenha direito a buscar judicialmente a efetivação de seu direito, recebendo em troca uma resposta fundamentada do Judiciário sobre a procedência ou não de seu pedido.

Ressalte-se, por relevante, que a eventual defesa de que o princípio deva ser concretizado de igual maneira em todas as esferas do Judiciário ou em todas as etapas do processo conduziria a duas conclusões danosas e insustentáveis: (i) permitiria que a pretensão de uma pessoa fosse ignorada desde o início pelo juiz natural, que estaria apto a ponderar a inafastabilidade do controle jurisdicional desde o primeiro ato processual, violando o que aqui se defendeu ser o núcleo de regra da norma e o próprio acesso à Justiça como conteúdo da dignidade humana; e (ii) conduziria à conclusão de que não cabe aos tribunais ou ao legislador impor limites à inafastabilidade jurisdicional, com o que se estaria a tratar da norma como regra, e não como princípio. Essa hipótese está em flagrante contradição com as condições fáticas de existência do Judiciário brasileiro - possuidor de taxas de congestionamento e de possibilidades recursais excessivas - e com a própria percepção da inafastabilidade como princípio.

Se partirmos do pressuposto, já devidamente assentado, de que a inafastabilidade, por ser princípio constitucional, possui uma dimensão de peso, faz-se necessário reconhecer que ela pode ser ponderada com outros princípios ou valores de igual hierarquia, em casos de colisão. Assim, do ponto de vista fático, os únicos momentos adequados para a ponderação da inafastabilidade se verificam em duas situações: (i) nas etapas recursais, por já ter havido resposta prévia do Judiciário à pretensão do jurisdicionado, e (ii) nos processos objetivos, onde não há propriamente pretensões subjetivas a serem respondidas pelo Judiciário.

No campo de atuação do juiz natural, portanto, a inafastabilidade gera uma obrigação no sentido de que o juiz natural ou a corte (nas hipóteses de competência originária) decida o caso. Tal obrigação, no entanto, não existe na esfera recursal ou do processo objetivo - como o de controle de constitucionalidade de natureza abstrata - na medida em que situações se encontram no halo externo do princípio e podem ser ponderadas tanto pelo legislador quanto pelo Judiciário.

Em razão disso, nenhuma liberdade tem o juiz natural para proferir decisões de non liquet, na jurisdição ordinária. Nesse caso, a atividade jurisdicional será indeclinável, por estar inserida no núcleo duro do princípio do acesso à justiça e representar importante faceta da própria dignidade da pessoa 
humana. ${ }^{53}$ É dizer: havendo uma pretensão por parte do jurisdicionado, há o direito de receber uma resposta do Poder Judiciário. Sem essa percepção, corre-se o risco de se esvaziar completamente os outros direitos fundamentais, tendo em vista a importância instrumental do acesso à justiça.

Contudo, conforme já foi adiantado, a situação se modifica na medida em que se sobe de grau jurisdicional. Com efeito, como o órgão revisor (via de regra, a segunda instância) encontra-se mais afastado do núcleo essencial do princípio da indeclinabilidade, em algumas situações poderá ser possível restringir o direito fundamental. Nesse sentido, pode ser legítima a restrição, por lei, dos recursos para a revisão de decisões proferidas pelo juiz natural. Ou seja, em grau de recurso, o princípio da inafastabilidade poderá ceder em favor de outros princípios (tais como os da celeridade e da razoável duração do processo $^{54}$ e da igualdade), em razão de determinadas situações fáticas e jurídicas. Afinal, uma justiça congestionada por um excessivo número de recursos pode representar a inexistência de qualquer justiça. A relação proporcional entre os instrumentos recursais previstos no ordenamento e a taxa de congestionamento das Cortes é intuitiva: a parte derrotada só encontra vantagens na possibilidade de recorrer, ainda que sem acreditar na validade de sua tese, tendo a oportunidade de prolongar os efeitos da decisão judicial ou até mesmo de revertê-la por algum lance de sorte. ${ }^{55} \mathrm{~A}$ inafastabilidade do controle jurisdicional não é o único princípio que deve pautar normativamente a atuação do Judiciário. Outros princípios de hierarquia constitucional, tais

53 Nessa direção, Ana Paula de Barcellos defende que, junto à assistência aos desamparados, à educação fundamental e à saúde básica, o acesso à justiça é parte da fração nuclear da dignidade humana, gozando de especial proteção, portanto. Nas palavras da própria autora: "O direito subjetivo de acesso à Justiça é o instrumento sem o qual qualquer dos três elementos anteriores torna-se inócuo, um 'sino sem badalo', na imagem inspirada do Professor José Carlos Barbosa Moreira. Em um Estado de Direito, como já se referiu, não basta a consagração normativa: é preciso existir uma autoridade que seja capaz de impor coativamente a obediência aos comandos jurídicos. Dizer que o acesso à Justiça é um dos componentes do núcleo da dignidade humana significa dizer que todas as pessoas devem ter acesso a tal autoridade". Ana Paula de Barcellos, A eficácia jurídica dos princípios constitucionais, op. cit., p. 293.

54 Sobre o surgimento desses princípios por meio da Emenda Constitucional no 45/04. José Afonso da Silva, Curso de direito constitucional positivo, op. cit., p. 432-433.

55 No caso brasileiro, conforme informações disponibilizadas pelo próprio Supremo Tribunal Federal, só naquele tribunal há um acúmulo de 40.686 feitos pendentes de decisão final e processos que já tiveram decisão final mas aguardam apreciação de recurso (agravo regimental, embargos de declaração, embargos de divergência e embargos infringentes), de outro pedido incidental, liberação de decisão ou acórdão para publicação, decurso de prazo processual, realização de comunicações ou outras providências. O número de casos em tramitação é incompatível com os princípios da celeridade e da duração razoável do processo. Disponível $\mathrm{em}:<\mathrm{www} . \mathrm{stf}$.jus.br/portal/cms/verTexto.asp?servico=estatistica\&pagina=acervoatual $>$. Acesso em: 24 set. 2014. 
como celeridade e a razoável duração do processo (art. 5, LXXVIII), devem ser cotejados com a inafastabilidade do controle jurisdicional.

O que se sustenta, aqui, é que a lei não poderá excluir, da apreciação do juiz natural (identificado, em regra, com o juiz de primeiro grau), lesão ou ameaça a direito, porque nessa instância a atividade jurisdicional corresponde ao núcleo essencial do princípio. É vedado ao legislador pretender impedir que as pessoas tenham seu dia na Corte. No entanto, em outras instâncias é possível restringir o princípio da inafastabilidade, diante de fundamentos constitucionais relevantes, que passem pelo teste da proporcionalidade.

Com efeito, tratando-se de competência recursal, sobretudo nos tribunais superiores - Tribunal Superior Eleitoral (TSE), Tribunal Superior do Trabalho (TST), Superior Tribunal Militar (STM), Superior Tribunal de Justiça (STJ) e Supremo Tribunal Federal (STF) -, o princípio estará sujeito a ponderações, por estar distante do seu núcleo essencial. A inafastabilidade do controle jurisdicional não é, pois, uma regra, que não pode ser ponderada. Ela é um princípio que deve encontrar seu ponto ótimo diante de outros princípios relevantes.

Em suma, ao mesmo tempo que se reconhece que o cidadão tem o direito fundamental de encontrar no Judiciário a efetividade para seus direitos, constituindo-se aí o núcleo de regra da inafastabilidade da tutela jurisdicional, defende-se que, em temas afetos aos tribunais superiores, por via recursal, e ao Supremo Tribunal Federal, em processos objetivos, não há a mesma garantia, pois tais hipóteses situam-se no halo principiológico da norma, sujeito a ponderações e a colisões.

Tal perspectiva, conforme demonstrado, encontra-se amparada pela teoria do direito, pelas conformações e limitações impostas pelo legislador ao tratar dos institutos recursais e pela própria produção jurisprudencial dos tribunais. Desse modo, qualquer perspectiva que pretenda propor um caráter de regra à inafastabilidade da tutela jurisdicional deverá se fundar em outros paradigmas da teoria do direito e encontrar argumentos relevantes o suficiente para superar ou, ao menos, melhor explicar a ampla produção jurisprudencial e legislativa pátria envolvendo o tema.

\section{Algumas consequências da tese proposta}

Qual a relevância, afinal, de se investigar a natureza jurídica da inafastabilidade do controle jurisdicional e de se identificar o seu núcleo 
essencial? A partir da tese proposta extraem-se três importantes conclusões para a dogmática jurídica, que serão apresentadas a seguir.

\subsection{Possibilidade de redução dos recursos cabiveis, bem como de restrição aos requisitos de admissibilidade, sem infração ao princípio da inafastabilidade do controle jurisdicional}

A análise empreendida põe novas luzes sobre a discussão a respeito da possibilidade de simplificação e redução do número de recursos existentes no ordenamento jurídico. Ela evidencia, em primeiro lugar, que não há um direito absoluto ao duplo grau de jurisdição, ${ }^{56}$ de modo que o legislador pode, legitimamente, restringir o número de recursos cabíveis. ${ }^{57}$ Corrobora o argumento o fato de que o art. 102, III, da Constituição, a contrario sensu, permite ao legislador criar procedimentos em única instância.

Com efeito, se os juízes naturais das causas atuam no núcleo essencial do princípio da inafastabilidade do controle jurisdicional, tem-se que, para eles, o princípio funcionará como regra. Ou seja, os juízes naturais não podem deixar de julgar uma demanda (non liquet). No entanto, na medida em que se sobe de grau de jurisdição e, por conseguinte, aumenta a distância do núcleo duro, o princípio volta a incidir como mandado de otimização, de modo que é possível restringir o número de recursos ou impor requisitos de admissibilidade mais rigorosos.

\subsection{Possibilidade de os Tribunais Superiores escolherem os recursos que desejam julgar}

O debate a respeito da abrangência do princípio da inafastabilidade do controle jurisdicional demonstra, ademais, que os Tribunais Superiores

\footnotetext{
56 O art. 108, II, da CRFB é exceção à regra. O dispositivo prevê, expressamente, o cabimento de recurso contra decisões proferidas por juízes federais. Em outras palavras, a partir da Constituição se consagra um direito ao duplo grau de jurisdição apenas na hipótese do art. 108, II. Veja-se: “Art. 108. Compete aos Tribunais Regionais Federais: (...) II — julgar, em grau de recurso, as causas decididas pelos juízes federais e pelos juízes estaduais no exercício da competência federal da área de sua jurisdição". Basta, no entanto, a previsão de cabimento de um único recurso para que a norma constitucional seja satisfeita.

57 Isso torna imperioso rever o entendimento jurisprudencial acerca do cabimento de Mandado de Segurança contra decisão judicial.
} 
podem escolher os casos que serão examinados, independentemente de a questão envolver, ou não, a rediscussão de aspectos fáticos.

É que, como os tribunais superiores, se situam na zona mais externa do âmbito de proteção do direito fundamental, o próprio tribunal pode ponderar a inafastabilidade do controle jurisdicional. Em outras palavras, os Tribunais Superiores, que têm competência de uniformização de entendimentos, podem deixar de analisar recursos excepcionais, mesmo quando preenchidos os requisitos de admissibilidade previstos na Constituição. Esta escolha, por evidente, deve ser minimamente motivada, nos termos do art. 93, IX, da CRFB.

Entendemos, portanto, com base no princípio da inafastabilidade do controle jurisdicional, que os Tribunais Superiores podem escolher as causas que desejam decidir, mesmo quando atendidos os requisitos de admissibilidade previstos na Constituição. Vale dizer: a competência recursal conferida pela Constituição não os obriga a julgar todos os recursos que lhes são submetidos e que atendem aos requisitos constitucionais e legais.

Adotadas essas premissas, deixam de ser importantes, da perspectiva da argumentação jurídica, diversas súmulas editadas pelo STF, pelo STJ e por outros Tribunais Superiores, que buscam reduzir o cabimento de recursos (súmulas que barram casos que envolvem a rediscussão de questões de fato, prequestionamento, cláusulas contratuais etc.). ${ }^{58}$ Pois, sem dependerem de súmulas anteriores, os Tribunais Superiores podem solucionar a colisão entre a inafastabilidade do controle jurisdicional e outros princípios, como a celeridade ou a razoável duração do processo.

Reduzir as possibilidades recursais disponíveis e permitir que os Tribunais Superiores tenham um maior espaço para selecionar os recursos que possuem relevância na ordem jurídica é primar pelo melhor funcionamento da Justiça e, simultaneamente, reafirmar a inexistência de um caráter absoluto para a inafastabilidade do controle jurisdicional.

\subsection{Possibilidade, em casos excepcionais, de prolação de juízos de non liquet}

As mesmas razões demonstram que é possível a prolação de juízos de non liquet, em circunstâncias excepcionais. Com efeito, o princípio da

58 Nessa direção, a título de exemplo, a dicção das Súmulas no 5, 7 e 211, do STJ e da Súmula no 356 do STF. 
inafastabilidade do controle jurisdicional não impõe que tudo, necessariamente, deva ser decidido definitivamente pelo Poder Judiciário. De longa data entende-se, por exemplo, que questões políticas são, via de regra, insuscetíveis de controle judicial. ${ }^{59}$ Nem por isso se alega que essa jurisprudência seria incompatível com o princípio da inafastabilidade.

Deve-se ter em mente, por outro lado, que não decidir jáé, em si, uma forma de decisão. Essa forma de decisão se justifica apenas em casos excepcionais e em fóruns especiais. O Judiciário nem sempre é o local adequado para se travar algumas discussões. Assim, o non liquet pode ser uma forma de decisão válida, para solucionar questões altamente controvertidas, que envolvam, v.g., desacordos morais insolúveis. Em casos como tais, o non liquet pode desempenhar um importante papel no desenvolvimento, efetivo, de um diálogo institucional entre os Poderes, a partir do qual se abdica de um modelo de supremacia do Judiciário e se aceita que "(...) o sentido futuro da Constituição se dê através de um diálogo aberto entre as instituições políticas e a sociedade civil, em que nenhum deles seja o 'supremo', mas antes, que cada um contribua com suas capacidades institucionais". ${ }^{60}$

Juízos de non liquet são, em nossa compreensão, possíveis, via de regra (mas não exclusivamente), em processos objetivos de controle de constitucionalidade. Sim, porque, como esses processos não têm partes (no sentido técnico-jurídico), não há propriamente um interesse subjetivo que deva ser protegido. Os instrumentos processuais de controle objetivo e abstrato de constitucionalidade voltam-se, antes de tudo, à defesa da higidez da ordem jurídica e, apenas indiretamente, à proteção de direitos específicos de pessoas determinadas. E a ordem jurídica precisa reconhecer a possibilidade de suas instituições dialogarem. Nesse sentido, reconhecer a possibilidade de non liquet permite que o STF compartilhe com os outros poderes e com a própria sociedade o papel de intérprete da Constituição. ${ }^{61}$

59 Veja-se, exemplificativamente: “EMENTA. Agravo regimental. Mandado de segurança. Questão interna corporis. Atos do Poder Legislativo. Controle judicial. Precedente da Suprema Corte. 1. A sistemática interna dos procedimentos da Presidência da Câmara dos Deputados para processar os recursos dirigidos ao Plenário daquela Casa não é passível de questionamento perante o Poder Judiciário, inexistente qualquer violação da disciplina constitucional. 2. Agravo regimental desprovido" (STF, MS 25588 AgR, rel. min. Menezes Direito, Tribunal Pleno, j. em 2/4/2009, DJe 22/4/2009).

${ }^{60}$ Sobre diálogos institucionais, v. BRANDÃO, Rodrigo. Supremacia judicial versus diálogos institucionais. Rio de Janeiro: Lumen Juris, 2012. p. 287.

${ }^{61}$ O fato de o STF ter o monopólio da última palavra em matéria de proteção e guarda da Constituição não significa que ele tenha de dar a única palavra. 
Decisões de non liquet podem igualmente ser legítimas em processos coletivos ou nos quais se discuta a implementação de políticas públicas, na medida em que podem contribuir para mitigar as consequências negativas da excessiva judicialização da política. ${ }^{62}$ Com efeito, muitas vezes o melhor que o Poder Judiciário poderá fazer será aguardar e acompanhar o processo de implantação de uma determinada política pública, sem se imiscuir nessa decisão. ${ }^{63}$

Tal posição, inclusive, não é de todo inédita no tratamento das relações entre Poder Judiciário e poderes políticos. Em matéria de políticas públicas, Ana Paula de Barcellos defende, por exemplo, ser razoável aguardar a conclusão de investigação levada a efeito pelo Tribunal de Contas competente acerca do atingimento ou não de metas fixadas para implantação de políticas públicas. Ainda que não seja esse o foco da argumentação da autora, podese dizer que ela sustenta uma autorrestrição, pelo Judiciário, do princípio da inafastabilidade do controle jurisdicional em respeito ao princípio da eficiência (art. 37, caput), evitando que dois órgãos públicos gastem recursos de maneira redundante na avaliação dos critérios de implementação. ${ }^{64}$

Filosoficamente, é de grande valia a posição de Daniel Sarmento e Claudio Pereira de Souza Neto. Ao descreverem o minimalismo judicial, corrente que sustenta que o Judiciário não deve se pronunciar além do que for necessário para resolver o caso e nem se enveredar em discussões filosóficas, os autores defendem que a assunção dessa teoria, embora não deva ser generalizada no caso brasileiro, pode alertar para os riscos de "certa intoxicação do discurso jurisdicional por construções teóricas e filosóficas muito abrangentes e pretensiosas". ${ }^{65}$ Assim, não é difícil defender que a adoção do non liquet por

62 Sobre judicialização da política, veja-se BARROSO, Luís Roberto. Constituição, democracia e supremacia judicial: direito e política no Brasil contemporâneo. Disponível em: <www. lrbarroso.com.br/pt/noticias/constituicao_democracia_e_supremacia_judicial_11032010.pdf>. Acesso em: 12 mar. 2012. Veja-se, também, BARROSO, Luís Roberto. Da falta de efetividade à judicialização excessiva: direito à saúde, fornecimento gratuito de medicamentos e parâmetros para a atuação judicial. Interesse Público, v. 36, n. 31, p. 31-61, 2007.

63 A verdade é que os instrumentos processuais hoje disponíveis são insuficientes para lidar com a implementação de políticas públicas pelo Poder Judiciário. É preciso, nesse sentido, repensar as normas processuais de tal forma que seja possível: (i) ao Poder Judiciário não intervir inicialmente em uma política pública (realizando juízos de non liquet), para aguardar alguns resultados futuros, reservando-se a julgar a questão oportunamente, diante de elementos mais concretos; ou (ii) proferir decisões condicionais.

64 BARCELLOS, Ana Paula de. Constitucionalização das políticas públicas em matéria de direitos fundamentais: o controle político-social e o controle jurídico no espaço democrático. Revista de Direito do Estado, Rio de Janeiro, n. 21, p. 155, jan./dez. 2011.

65 SOUZA NETO, Claudio Pereira de; SARMENTO, Daniel. Direito constitucional: teoria, história e métodos de trabalho. 2. ed. Belo Horizonte: Fórum, 2014. p. 225-227. 
um tribunal de grande relevância política como o STF seria um eficiente instrumento para a adoção de uma postura minimalista nos casos em que ela seja conveniente.

Não se pode deixar de salientar, por fim, que, embora o STF defenda, em sua jurisprudência, a proibição de non liquet, a verdade é que a tese proposta não é de todo estranha ao Tribunal. Pode-se afirmar, sem riscos, que o Supremo Tribunal Federal profere non liquet, por exemplo, quando, decidindo embargos de declaração, sustenta que: “o magistrado não está obrigado a responder todos os fundamentos alegados pelo recorrente. (...) Este Tribunal fixou entendimento no sentido de que o magistrado não está vinculado pelo dever de responder todos os fundamentos alegados pela parte recorrente. Precedentes. $(\ldots)^{\prime \prime} .{ }^{66}$

De igual forma, também é possível sustentar que a repercussão geral institucionalizou uma nova forma de non liquet, ao permitir que o Tribunal deixe de julgar casos cuja eventual violação à Constituição seja de menor repercussão para a sociedade. Tais casos promovem a celeridade e a razoável duração do processo, em detrimento da inafastabilidade do controle jurisdicional, em linha com a tendência adotada na maior parte das cortes constitucionais do mundo. ${ }^{67}$ Essa, também, parece ter sido a opção da Lei n⿳o $12.016 / 2009$, que, em seu art. 5o, condiciona a impetração de mandado de segurança à impossibilidade de interposição de recurso administrativo dotado de efeito suspensivo. ${ }^{68}$

\section{Conclusão}

À luz da teoria dos princípios, conclui-se que a garantia da inafastabilidade do controle jurisdicional ostenta características de princípio jurídico, aplicável de acordo com as condições fáticas e jurídicas subjacentes. Tal princípio possui âmbito de proteção normativo, o que significa dizer que o legislador ordinário tem um importante papel para viabilizar o exercício desse direito, devendo estabelecer procedimentos e mecanismos que permitam o acesso à justiça.

66 STF, RE 511.581-AgR, rel. min. Eros Grau, Segunda Turma, j. em 24/6/2008, DJ de 15/8/2008.

67 BARROSO, Luís Roberto. O controle de constitucionalidade no direito brasileiro: exposição sistemática da doutrina e análise crítica da jurisprudência. São Paulo: Saraiva, 2011. p. 132.

68 Art. 5o Não se concederá mandado de segurança quando se tratar: I - de ato do qual caiba recurso administrativo com efeito suspensivo, independentemente de caução; (...). 
No entanto, apesar de a conformação legislativa ser necessária, é vedada a realização de intervenções que possam afetar a proteção judicial efetiva. Há um limite para a atividade conformadora e restritiva dos direitos fundamentais, que é o respeito ao seu núcleo essencial.

Há basicamente duas teorias que buscam explicar como alcançar o núcleo essencial de um direito fundamental, que servirá de limite dos limites: as teorias absoluta e relativa. Em regra, os defensores da teoria absoluta sustentam que, antes mesmo de iniciar um processo de ponderação, é possível identificar que prerrogativas dos direitos envolvidos não podem ser restringidas. Já os adeptos da teoria relativa consideram que o núcleo essencial só pode ser identificado no caso concreto, após o processo de ponderação. Não há conteúdo em abstrato que não possa sofrer restrições. Ambas as teorias são passíveis de críticas. Nada obstante isso, o núcleo essencial teria pouca ou nenhuma valia como limite dos limites caso se adotasse a teoria relativa. Daí por que adotamos uma teoria absoluta, temperada. Nesse sentido, como sustenta Ana Paula de Barcellos, cumpre à doutrina e à jurisprudência a proposição de parâmetros e standards para facilitar a identificação do núcleo essencial de cada direito. Esse núcleo tem natureza de regra e não poderá sofrer restrição ou ser relativizado em nenhuma circunstância.

No caso específico da inafastabilidade do controle jurisdicional, a intensidade da incidência do princípio depende do grau de jurisdição e varia verticalmente: o núcleo essencial do princípio situa-se no primeiro grau de jurisdição, ao passo que seu halo mais externo encontra-se nos Tribunais Superiores. Por essa via, extraem-se duas importantes consequências da adoção dessa tese: (i) os juízes de primeiro grau não podem deixar de julgar os casos que lhe são submetidos, mas, nos tribunais de segundo grau, pode, eventualmente, ser proferida decisão de non liquet; (ii) o legislador pode reduzir os recursos processuais cabíveis, bem como restringir os requisitos de admissibilidade, sem violar o princípio da inafastabilidade do controle jurisdicional.

Do ponto de vista da aplicação prática, a constatação da natureza principiológica da inafastabilidade do controle jurisdicional obriga que a mesma seja aplicada de maneira ótima diante de colisões com outros princípios, tais como a celeridade ou a razoável duração do processo. Tratase do caso, por exemplo, da inclusão do requisito da repercussão geral nos recursos extraordinários. Além disso, do ponto de vista dos diálogos institucionais, permite que o STF profira juízos de non liquet aumentando, portanto, a dimensão do debate público e fazendo com que o órgão divida 
seu papel de intérprete da Constituição com o resto da sociedade, mitigando, por consequência, o fenômeno do ativismo judicial.

\section{Referências}

ALEXY, Robert. Teoria dos direitos fundamentais. Tradução de Virgílio Afonso da Silva, São Paulo: Malheiros, 2008.

BARCELLOS, Ana Paula de. A eficácia jurídica dos princípios constitucionais: o princípio da dignidade da pessoa humana. Rio de Janeiro: Renovar, 2002.

- Constitucionalização das políticas públicas em matéria de direitos fundamentais: o controle político-social e o controle jurídico no espaço democrático. Revista de Direito do Estado, Rio de Janeiro, n. 21, p. 123-160, jan./ dez. 2011.

2005.. Ponderação, racionalidade e atividade jurisdicional. Rio de Janeiro: Renovar,

BARROSO, Luís Roberto. Da falta de efetividade à judicialização excessiva: direito à saúde, fornecimento gratuito de medicamentos e parâmetros para a atuação judicial. Interesse Público, v. 36, n. 31, p. 31-61, 2007.

- Constituição, democracia e supremacia judicial: direito e política no Brasil contemporâneo. Disponível em: <www.lrbarroso.com.br/pt/noticias/ constituicao_democracia_e_supremacia_judicial_11032010.pdf>. Acesso em: 12 mar. 2012.

. O começo da história. A nova interpretação constitucional e o papel dos princípios no direito brasileiro. In: ___. Temas de direito constitucional. Rio de Janeiro: Renovar, 2005. t. III, p. 3-59.

. O controle de constitucionalidade no direito brasileiro: exposição sistemática da doutrina e análise crítica da jurisprudência. São Paulo: Saraiva, 2011.

BLACK, Henry Campbell. Black's law dictionary. 4. ed. St. Paul: West Publishing Co., 1951.

BRANDÃO, Rodrigo. Supremacia judicial versus diálogos institucionais. Rio de Janeiro: Lumen Juris, 2012.

CALLEJÓN, Francisco Balaguer; VILLAR, Gregorio Camara; AGUILAR, Juan Fernando Lopez; CALLEJÓN, Maria Luisa Balaguer. Manual de derecho constitucional. Madri: Grupo Anaya-Tecnos, 1990. 
CÂMARA, Alexandre Freitas. O acesso à justiça no plano dos direitos humanos. In: QUEIROZ, Raphael Augusto Sofiati de (Org.). Acesso à Justiça. Rio de Janeiro: Lumen Juris, 2002. p. 1-9.

CHELLI, Enzo; GRASSI, Stefano; BARILE, Paolo. Istituzioni di diritto pubblico. 7. ed. Altedo: Casa Editrice Dott. Antonio Milani, 1995.

DANTAS, Frederico Widson da Silva. O princípio constitucional da inafastabilidade: estudo com enfoque no ativismo judicial. Revista Emasfe Escola de Magistratura Federal da 5ạ Região, n. 17, p. 83-114, 2008.

DIDIER JR., Fredie. Notas sobre a garantia constitucional do acesso à justiça: o princípio do direito de ação ou da inafastabilidade do Poder Judiciário. Revista de Processo, n. 108, a. 27, p. 23-31, out./dez. 2002.

DWORKIN, Ronald. Levando os direitos a sério. Tradução de Nelson Boeira. 3. ed. São Paulo: WMF Martins Fontes, 2010.

GALDINO, Flávio. A evolução das ideias de acesso à justiça. In: SARMENTO, Daniel; GALDINO, Flavio (Org.). Direitos fundamentais: estudos em homenagem ao professor Ricardo Lobo Torres, Rio de Janeiro: Renovar, 2006. p. 431-471.

GAVARA DE CARA, Juan Carlos. Derechos fundamentales y desarrollo legislativo: la garantia del contenido esencial de los derechos fundamentales en la Ley Fundamental de Bonn. Madri: Centro de Estudios Constitucionales, 1994.

GERAIGE NETO, Zaiden. O princípio da inafastabilidade do controle jurisdicional: art. 5o, inciso XXXV, da Constituição Federal. São Paulo: Revista dos Tribunais, 2003. (Coleção Estudos de Direito de Processo - Enrico Tullio Liebman v. 56).

HART, H. L. A. O conceito de direito. Tradução de Antônio de Oliveira Sette Câmara. São Paulo: WMF Martins Fontes, 2009.

MARMELSTEIN, George. Curso de direitos fundamentais. 3. ed. São Paulo: Atlas, 2011.

. O asno de Buridano, o non liquet e as katchangas. Disponível em: <http:// direitosfundamentais.net/2009/01/07/o-asno-de-buridano-o-non-liquet-e-askatchangas/>. Acesso em: 10 dez. 2011.

MARTINS, Leonardo Resende. Acesso à justiça e efetividade constitucional. In: ___ A expansão do direito: estudos de direito constitucional e filosofia do 
direito em homenagem a Willis Santiago Guerra Filho: por duas décadas de docência e pesquisas. Rio de Janeiro: Lumen Juris, 2004. p. 301-315.

MENDES, Gilmar Ferreira; COELHO, Inocêncio Mártires; BRANCO, Paulo Gustavo Gonet. Curso de direito constitucional. São Paulo: Saraiva, 2007.

MENDES, Gilmar Ferreira. Direitos fundamentais e controle de constitucionalidade: estudos de direito constitucional. 3. ed., rev. e ampl., 2. tir. São Paulo: Saraiva, 2006.

MORO, José Ferrater. Dicionário de filosofia. Tradução de Roberto Leal. São Paulo: Martins Fontes, 1993.

NOVAIS, Jorge Reis. As restrições aos direitos fundamentais não expressamente autorizadas pela Constituição. Coimbra: Coimbra, 2003.

PEREIRA, Jane Reis Gonçalves. Aspectos gerais sobre a restrição de direitos fundamentais. Disponível em: <http://works.bepress.co/cgi/viewcontent. cgi? article=1007 \&context=janereis>. Acesso em: 1 out. 2014.

. Interpretação constitucional e direitos fundamentais: uma contribuição ao estudo das restrições aos direitos fundamentais na perspectiva da teoria dos princípios. Rio de Janeiro: Renovar, 2006.

RIBERO, Willman Ruperto Durán. Los derechos fundamentales como contenido esencial del estado de derecho. Anuario de Derecho Constitucional Latinoamericano, p. 183-191, 2003.

SANCHÍS, Luis Prieto. Diez argumentos a propósito de los princípios. In: . Ley, principios, derechos. Madri: Dykinson, 1998. p. 47-68.

SARMENTO, Daniel. A ponderação de interesses na Constituição Federal. Rio de Janeiro: Lumen Juris, 2000.

SERNA, Pedro; TOLLER, Fernando M. La interpretación constitucional de los derechos fundamentales: una alternativa a los conflictos de derechos. Buenos Aires: La Ley, 2000.

SILVA, José Afonso da. Curso de direito constitucional positivo. 27. ed. São Paulo: Malheiros, 2006.

SILVA, Virgílio Afonso da. A constitucionalização do direito: os direitos fundamentais nas relações entre particulares. São Paulo: Malheiros, 2005.

. Direitos fundamentais: conteúdo essencial, restrições e eficácia. 2. ed., 2. tir. São Paulo: Malheiros, 2011. 
. O conteúdo essencial dos direitos fundamentais e a eficácia das normas constitucionais. Revista de Direito do Estado, Rio de Janeiro, a. 1, n. 4, p. 23-52, out./dez. 2006.

SOUZA NETO, Claudio Pereira de; SARMENTO, Daniel. Direito constitucional: teoria, história e métodos de trabalho. 2. ed. Belo Horizonte: Fórum, 2014.

SULLIVAN, Kathleen. Foreword: the justice of rules and standards. Harvard Law Review, Cambridge, n. 106, p. 22-123, 1992.

TORRES, Ricardo Lobo. O mínimo existencial como conteúdo essencial dos direitos fundamentais. In: . Direitos sociais: fundamentos, judicialização e direitos sociais em espécie. Rio de Janeiro: Lumen Juris, 2010.

VIEIRA, Oscar Vilhena. Direitos fundamentais: uma leitura da jurisprudência do STF. São Paulo: Malheiros, 2006. 